\title{
FACTORS AFFECTING THE INDEPENDENCE OF GOVERNMENT AUDITORS OF BPKP REPRESENTATIVE OF EAST KALIMANTAN PROVINCE
}

\author{
Irwansyah \\ FibriyaniNurKhairin \\ NurAini \\ Email:aini.nur0797@yahoo.com
}

\author{
ARTICLE INFORMATION \\ Article history: \\ Received July31, 2015 \\ Revised November 15, 2015 \\ Accepted April 16, 2016

\section{JEL Classifications} \\ M42
}

\section{Key Words:}

Audit experience,

Knowledge,

Job Stress Scale,

Reward,

Government,

Auditor Independence

\section{DOI:}

10.21532/apfj.001.16.01.02.20

\begin{abstract}
This study aims to determine whether the factors consisting of audit experience, knowledge, job stress scale, and reward may affect the independence of government auditors. This study uses primary data obtained from questionnaire. The population in this study is as many as 103 government auditors working at the Finance and Development Supervisory Agency (BPKP) of East Kalimantan Province with a total sample of 33 government auditors. The analysis tool used is multiple linear regression formula, while the hypothesis test is conducted using model feasibility test ( $F$ statistic test) and partial significance test (t statistic test). The result of simultaneous hypothesis test indicates that audit experience, knowledge, job stress scale, and reward simultaneously have positive effect on the independence of the government auditors. The result of partial significance test indicates that: (1) audit experience has no effect on the independence of the government auditors, (2) knowledge has positive effect on the independence of the government auditors, (3) job stress scalehas no effect on the independence the government auditors, and (4) reward has no effect on the independence of the government auditorsofthe Finance and Development Supervisory Agency $(B P K P)$ Representative ofEast Kalimantan Province.
\end{abstract}

\section{INTRODUCTION}

The rampant cases of corruption, collusion and nepotismon various aspects in Indonesia in recent years have prompted the government to have a big commitment to eradicate them completely. As mandated by the People's 
Consultative Assembly (MPR) in the Decree No. XI / MPR / 1998 and Law No. 28 of 1999 on the implementation of clean government which is free of corruption, collusion, and nepotism, the eradication of such cases has become acrucial agenda that should be implemented in order to achieve transparency and public accountability.

Today, the implementation of public accountability by government agencies in Indonesia is supported by supervision services conducted by the Government Internal Supervisory Apparatus (APIP). APIP, or better known as government auditors, are civil servants whose task is not only as civil servants but also as auditors. APIP auditors, consisting of auditors within the Finance and Development Supervisory Agency (BPKP), General Inspectorate of Ministry, Control Unit of NonMinisterial Government Institutions (LPND), and the Inspectorate of Province, District, and City, in implementing their duties shall adhere to the APIP Code of Ethicsrelated to their status as civil servants, and APIPAuditing Standardsas stipulated in the Regulation of the Ministry forState Apparatus Reforms No. PER / 04 / M.PAN / 03/2008 dated March 31, 2008 (Code of Ethics and Auditing Standards, 2008). According toBadjuri (2012), one of the purposes of the establishment of APIP Code of Ethics is to prevent unethical behavior. In the Code of Ethics and Auditing Standards (KESA), one of Auditing Standards that must be obeyed by APIP is the second common standard with regard to the necessity of APIP auditors to keep their independency.
According to the Code of Ethics of Indonesian Accountants attached in the Code of Ethics and Auditing Standards (KESA) and established by the Finance and Development Supervisory Agency (2008), the factorsaffecting the independence of an auditor, among others are: financial relationship with the client, position in the company audited, involvement in inappropriate and inconsistent business, implementation of other services to an audit client, family and personal relationships, reward for professional services, receipt of goods or services from clients, and provision of goods or services to client. In his research ofthe internal and external factors that influence the independence of auditor, Ec. HannyWurangian and MuslichAnshori (2006) state that there are 7 (seven) factors that affect the independence of auditor: quality of auditor, financial capacity of auditor, auditor's relationship with client, size of client, period of audit, audit handling period, and adherence to the provisions. In contrast to Gabriel Henry WilliChoandy (2012), that there are four (4) factors that may affect the independence of an auditor: audit experience, job stress scale, knowledge, and reward and punishment.

Discussion on the eradication of corruption, corruption and nepotism, the public accountability, and the independence makes the writers attracted to examine the independence of government auditors in the Finance and Development Supervisory Agency (BPKP), in which the eradication of corruption and public accountability cannot be separated from the main tasks and functions carried out by BPKP, 
as regulated by Decision of the Head of BPKP No. 06:00:00 -286 / K / 2001 on Organization and Work Procedures of BPKP Representative, as amended several times and last amended by Regulation of the Head of BPKP No. 11 of 2013 on the Seventh Amendment to the Decision of the Head of BPKP No.KEP-06.00.00-286 / K / 2001 on the Organization and Work Proceduresof BPKP Representative. In article 2 states that BPKP has the task of carrying out government duties in the field of financialand development supervision in accordance with the provisions of the legislation in force. One of its functions is to conduct an investigation of irregularity indications that harm the country, State-Owned Enterprises and other agencies therein contained government interests, the examination of barriers to the smooth development, and the provision of inspection assistance to the investigator and other Government Agencies. In implementing the main tasks and functions, the independence or impartiality of an auditor is indispensable.

The formulation of the problem in this research is as follows: Do audit experience, knowledge, job stress scale, and reward, which are owned or received by government auditors, affect the independence of the government auditors of BPKP Representative of East Kalimantan Province?

In accordance with the formulation of the problem above, this research is conducted in order to reveal and obtain empirical evidence about: the influence of audit experience, knowledge, job stress scale, and reward on the independence of government auditorsof BPKP Representative of East Kalimantan province.

\section{TEORETICAL REVIEW AND HYPOTHESIS}

\section{Theory of Attitude and Behaviour}

Theory of Attitude and Behavior developed by Triandis (1971) in Kasidi (2007) is seen as the underlying theory to explain independence. The theory holds that the behavior is determined by what people want to do for (attitude), what they think they will do (social rules), what they can do (customs) and the behavioral consequences of what they think. Attitude has relationship with cognitive components related to confidence, whereas affective attitude component has a connotation of like or dislike.

Attitude is an evaluative statement regarding all the actions that we do, whether favorable or unfavorable. Attitude can also be regarded as a tendency to give a response to something. Attitude is not the same as behavior, but attitude produces something that leads to behavior, so it can be said that attitude is one tool in guiding behavior. Attitude not only appears on the basis of the circumstances at hand, but also related to the experiences and or hope for the future. This is reinforced by the statement of ArfanIkhsanLubis (2009: 78) that

"Attitude is something to learn the
whole tendency of action, either
favorable or unfavorable, human
purpose, object, idea, or situation.
Attitude is nota behavior, but
attitude represents preparedness
for action that leads to behavior.
Attitude hasbeen studied,
developed well, and difficult to
change. People derive attitude
from personal experience, parents,
role models, and social groups".

"Attitude is something to learn the whole tendency of action, either favorable or unfavorable, human purpose, object, idea, or situation. Attitude is nota behavior, but attitude represents preparedness for action that leads to behavior. Attitude hasbeen studied, developed well, and difficult to change. People derive attitude role models, and social groups ".
rol 
According to Kasidi (2007), attitude has the function of understanding, the need for satisfaction, ego defense, and expression of values. Understanding serves to help a person in giving meaning or understanding the situation or event. Attitude also servesas something beneficial or as the need for satisfaction. Attitude also serves as an ego defense by making development to protect human from the knowledge which is based on the truth about the basis of the man himself or his world, and eventually attitude also serves as an expression of values to achieve satisfaction. This is reinforced by the statement ofArfanIkhsanLubis (2009: 80) that "Attitude allows someone to assess a new situation quickly without needing to gather all relevant information about the situation".

\section{Independence}

Independence is a term which is often used by professional accountants or auditors. Independence is one of the components of ethics that must be constantly guarded by an auditor. In performing his duties, an auditorshall not be partial to the interests of anyone, as stated in KESA (2008) "In all matters relating to audit, APIP auditors must be independent and objective in the execution of their duties".

Mulyadi (2008: 26) in IkaPermata Indah (2011) states that independence is a mental attitude that can neither be influenced nor controlled by other parties, and does not depend on other parties. Independence means thatthere is honesty within the auditor in considering the facts and there is objective or impartial consideration within the auditor to formulate and express his opinions. Essentially, independence is a person's mindset characterized by the attitude of integrity and objectivity to his professional duties.

This is consistent with the American Institute of Certified Public Accountants (AICPA) and Kell et al. (1989) which state that independence is an ability to act based on the integrity and objectivity. Integrity means honest and trustworthy, while objectivity is an attitude related to the ability of each member of public accounting profession to have a fair and impartial attitude in all matters related to his professional duties (FriskaNovitasari, 2004). It can be concluded that independence is the auditor's independence from the auditee, either from internal or external environment of the auditor.

According to SukrisnoAgoes (2012: 34), independence is divided into three types, namely:

1. Independent in Appearance (independence is viewed from his appearance in the organizational structure of the company)In Appearance, Public Accountant is independent because he is the party outside the company.

2. Independent in Fact (independencein performing his duties) In Fact, public accountant should be independent, in performing his duties he always provides professional services, he can maintain the integrity and always adheres to the Code of Professional Ethics 
of Certified Public Accountants and Public Accountants Professional Standards. Otherwise, a public accountant is in-fact not independent.

\section{Independent}

in

Mind

For instance, an auditor obtains an audit finding which has indication of violation or corruption, or which requires a material audit adjustment. Then he is thinking of using the audit finding to squeeze the auditee. Although it is just a thought, and has not been done, the in mind of the auditor has lost its independence

In contrary toSukrisnoAgoes, according to KESA (2008), independence is essentially a state of mind or something felt by each person according to what is believed to be ongoing. In connection with this, the independence of auditor can be reviewed and evaluated from two sides, the independence of the practitioner and the independence of the profession. The independence of the practitioner is the real or factual independence acquired and retained by the auditor in a whole series of audit activities, from planning and implementation to reporting stage. While the independence of the profession is the independence which is reviewed in the image of the auditors from the public view or the general public on the auditor in charge. The independence under this review is often also called independence in appearance.

\section{Audit Experience}

Implementing audit requireshigh expertise and professionalism. Expertise is influenced not only by formal education, but also by other factors, such as experience. KESA (2008) explains that an auditor must have competence. In carrying out the duties, anauditor is required to have the knowledge, expertise, experience and skills required. And in carrying out the task of supervision, an auditor acts in accordance with auditing standards, as mentioned in auditing standards of APIP that in all matters relating to audit, APIP auditors must be independent andobjective. Indirectly it can be said that the independence of a government auditor may be impaired due to the inadequacy of his competence. And the inadequate competence is supported by a factor of inadequate auditing experience owned by a government auditor.

This is in line with the statement of Gabriel Henry Willy Choandy (2012) that an auditor becomes an expert mainly acquired through training and experience. A more experienced auditor will have a better scheme in defining errors than the less experienced auditors. Furthermore, Gabriel Henry Willy Choandy (2012) explains that an experienced auditor has advantages in terms of detecting errors, understanding faults accurately, and looking for the causes of the errors. It can be concluded that, the higher the level of experience of an auditor, the more sensitive the auditor to unusual errors that occur in the field. The more sensitive the auditor with unusual errors that occurin the field, the higher the understanding of the auditor on other matters related to the errors he found. 


\section{Knowledge}

An auditor, who has extensive education, will indirectly have a broader view on various things. The auditor will increasingly have a lot of knowledge about the field that he does, so that the auditor can easily figure out the various issues more deeply. In addition, the presence of adequate knowledge will enable the auditor to follow the development whichis increasingly complex. The complex audit analysis requires expertise, knowledge and extensive experience.

According to APIP Auditing Standards, on the part of the General Standards No. 3 (KESA, 2008), explains that APIP auditors must have knowledge, skills and other competencies needed to perform their responsibilities. In performing responsibilities with a range of knowledge, skills and competencies owned, the government auditors, or APIP, are expected to maintain their independence.

According to Gabriel Henry Willy Choandy (2012), to perform auditing tasks, an auditor requires knowledge of auditing (general and specific), knowledge about the field of auditing and accounting, and understandingof the client's industry. Therefore, what is meant by knowledge in this research is all knowledge owned by the auditor which includes auditing (both general and specific), knowledge about the field of auditing and accounting, as well as the understandingof the client's industry (types of client's organizations).

\section{Job Stress Scale}

Stress is a condition in which the tension affects emotion, thinking process, as well as person's condition. Too large stress may result in a threat to someone who experiences it, especially in his attitude to face his environment. According to Gabriel Henry Willy Choandy (2012), stress can be defined as a condition that suppresses a person's mental state in achieving an occasion. In which to achieve this occasion there is a limit or barrier.

If the term stress isassociated with this study, so stress is a condition that can affect the physical and psychological state of the government auditor, and thus affecting his independence because of the pressure from within and outside him. According to Gabriel Henry Willy Choandy (2012), workload or job stress, such as pressure from clients, personal stress, emotion or financial condition, can reduce the independence of the auditor and affect the audit quality.

\section{Reward}

According to Gabriel Henry Willy Choandy (2012), one of the factors that are considered influencing the ethical attitude and behavior of an auditor, in addition to the factors of religiosity, education, organizational, emotional quotient, family environment, life experiences, the law, and the position, is the reward received.The factor of reward, in the form of gifts received by the auditor when performing examination, could affect the independence of the auditor. The higher the reward received by the auditor, the higher the level of maturity in any decision making that might affect his independence.

This is similar to a statement issued by Mintz in Messier, William F., et el (2009: 376) regarding utilitarian theory. Utilitarian theory 
recognizes that decision makingincludes a choice between the benefits and the burdens of alternative measures, and focuses on the consequences of the actions on the influenced individual. This theory proposes that the influence includes not only one's own interests, but also the interests of all parties. This is what is then taken into consideration.

It is described again by Mintz in Messier, William F., et el (2009: 376) that from this perspective, an action will adjust to the principle of utility only if such action results in more pleasure or happiness (or preventing more misery or sadness) than other possible actions.

In line with Gabriel Henry Willy Choandy and Mintz, the code of ethics and auditing standards issued by BPKP in 2008 suggests that reward for professional services could affect the auditor independence.

\section{Theoretical Framework}

Theoretical framework is formed from theories and explanations of the theories which state the independence of government auditorcan be affected by several variables, including the variables of audit experience, knowledge, job stress scale and reward. So, the theoretical framework can be made as follows.

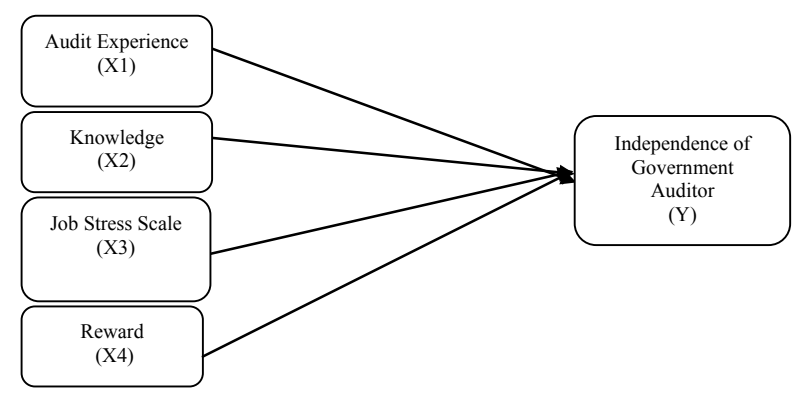

Framework Concept

\section{Hypothesis Formulations}

The hypothesis in this study is as follows: H1 : The audit experience owned by the government auditors(X1) has positive effect on the independence of the government auditors(Y) ofBPKP Representative of East Kalimantan Province.

H2 : The knowledge owned by the government auditors (X2) has positive effect on the independence of the government auditors(Y) ofBPKP Representative of East Kalimantan Province.

H3 : The job stress scale experienced by the government auditors(X3) has negative effect on the independence of the government auditors(Y) ofBPKP Representative of East Kalimantan Province.

H4 : Therewardreceived by the government auditors(X4) has positive effect on the independence of the government auditors(Y) ofBPKP Representative of East Kalimantan Province.

\section{RESEARCH METHOD \\ Operational Definition \\ Dependent Variable}

The independence of government auditor (Y) is the independence of the government auditor from the auditee, either from internal or from external environment of the auditor. The independence of government auditor declares an attitude of honesty from within the government auditor himself by considering the objective 
facts andthe impartiality of government auditor in formulating and expressing his opinion or the results of his findings. The indicators of the independence of government auditor, among others, are: free of financial conflicts of interest, a strong commitment in the completion of the audit, using APIP Professional Standards and Government Accounting Standards (SAP) as guidelines for field work; not easy to believe the information given by the auditee during the audit process; and being cautious in decision making.

\section{Independent Variable}

1. Audit experience (X1) is the accumulation of all the results of interactions done repeatedly by the auditor in the audit. The indicators of the variable of audit experience include working lives and the number of audit clients.

2. Knowledge (X2) is the science owned by auditor which includes auditing (general and specific), the science in the field of auditing, accounting and understanding the client's industry. The indicators of the variable of knowledge include the ability to analyze the information obtained, careful attitude towards any issue related to the examination, knowledge of accounting principles and auditing standards, formal education, training, and courses, as well as specialized skills.

3. The job stress scale (X3) is a condition that can affect the physical and psychological state of government auditor, which in turn could affect his independence because of pressure from within and from outside.
The indicators of the level job stress are pressures on the job at hand, the level of passion for the job, enthusiastic attitude towards the job, habit to overtime, attitude of loyalty towards the organization, and obedient attitude towards rules and regulations that apply in each assignment.

4. Reward (X4) is a reward received by government auditor from agencies or government institutions for the work he does, both material and non-material. The indicators of reward are compensation received and many opportunities for career development.

\section{Population and Sample}

The population in this study consists of all government auditors existing in BPKP Representative of East Kalimantan province. The samples used in this study will be taken using probability sampling techniques with simple random sampling. The use of probability sampling techniques with simple random sampling is because every element in the population has the same chance to be sampled. To determine the number of samples (sample size) of the population can be calculated using slovinformula as follows (Iqbal, 2002 in Nike Rimawati, 2011):

$$
\mathrm{n}=\frac{\mathrm{N}}{1+\mathrm{Ne}^{2}}
$$

Explanation:

$$
\begin{array}{ll}
\mathrm{n} & \text { : sample } \\
\mathrm{N} & \text { : population } \\
\mathrm{e} & \text { : percentage of inaccuracy looseness } \\
& \text { due to sampling errors that are still } \\
& \text { tolerable or desirable, } 10 \% .
\end{array}
$$

\section{Asia Pasific Fraud Journal}

Volume 1, No.2 ${ }^{\text {nd }}$ Edition (july-December 2016) 
The population size in this study is 103 government auditors with a looseness percentage of $10 \%$ due to the response rate of respondents to questionnaires distributed by the researchers are still low. Thelow response rate of the respondents to the questionnaires distributed in this research because, considering the condition that occurs in the field, the government auditors who work on BPKP Representative of East Kalimantan Province sometimes get out of town assignment in such a long time, so it does not allow them to be able to complete and return the questionnaire to the researchers promptly. Hence the number of samples can be determined as follows.

$$
\begin{aligned}
& \mathrm{n}=\frac{\mathrm{N}}{1+\mathrm{Ne}^{2}} \\
& \mathrm{n}=\frac{103}{1+103(10 \%)^{2}} \\
& \mathrm{n}=50,7=51
\end{aligned}
$$

Table of Research Population

\begin{tabular}{|l|c|}
\hline Position & $\begin{array}{c}\text { Number of HR } \\
\text { (people) }\end{array}$ \\
\hline Structural & 4 \\
\hline Associate Auditor & 10 \\
\hline Young Auditor & 18 \\
\hline First Auditor & 5 \\
\hline Skilled Auditor & 40 \\
\hline $\begin{array}{l}\text { Candidate of } \\
\text { Functional Auditor }\end{array}$ & 26 \\
\hline Total & 103 \\
\hline
\end{tabular}

Table of Research Sample Proportion

\begin{tabular}{|l|l|l|l|}
\hline Position & $\begin{array}{l}\text { Number } \\
\text { of HR } \\
\text { (people) }\end{array}$ & $\begin{array}{l}\text { Sample } \\
\text { Proportion }\end{array}$ & $\begin{array}{l}\text { Number of } \\
\text { Sample }\end{array}$ \\
\hline Structural & 4 & $4 / 103 \times 51$ & 2 \\
\hline $\begin{array}{l}\text { Associate } \\
\text { Auditor }\end{array}$ & 10 & $\begin{array}{l}10 / 103 \times \\
51\end{array}$ & 5 \\
\hline $\begin{array}{l}\text { Young } \\
\text { Auditor }\end{array}$ & 18 & $\begin{array}{l}18 / 103 \times \\
51\end{array}$ & 9 \\
\hline First Auditor & 5 & $5 / 103 \times 51$ & 2 \\
\hline $\begin{array}{l}\text { Skilled } \\
\text { Auditor }\end{array}$ & 40 & $\begin{array}{l}40 / 103 \times \\
51\end{array}$ & 20 \\
\hline $\begin{array}{l}\text { Candidate } \\
\text { ofFunctional } \\
\text { Auditor }\end{array}$ & 26 & $\begin{array}{l}26 / 103 \times \\
51\end{array}$ & 13 \\
\hline Total & 103 & & 51 \\
\hline
\end{tabular}

\section{Types and Data Source}

Types of data used in this study are primary data and secondary data. The source of primary data in this study is a written response from the government auditors of BPKP Representative of East Kalimantan Province through questionnaires distributed directly. Meanwhile, the source of secondary data in this study is the profile of BPKP Representative of East Kalimantan Province obtained directly from BPKP Representative of East Kalimantan Province.

\section{Data Collection Technique}

To obtain necessary data, the writers use some data collection techniques which are customized with the title of the study. The data collection techniques are as follows.

1. Field Work Research

That is the data obtained directly from the field or directly from the object of 
research by questionnaires. The research data are obtained by distributing the questionnaires to the government auditors of BPKP Representative of East Kalimantan Province directly (without going through the post). In addition, a letter of application research is attached to the questionnaires. The space for respondent's identity (respondent's name) is provided in the questionnaire, but to maintain the confidentiality of the identity of the respondent, the respondent does not have to write his name. Instructions on filling in the questionnaire are made as simple as possible, by putting a check mark $(\sqrt{ })$ in the column that has been provided in accordance with the opinion of a number of alternative answers provided.

\section{Library Research}

That is the data obtained by reading literatures in the form of text books and scientific journals related to the variables studied.

\section{Scale of Research}

Questions or statements in the questionnaire for each variable in this study are measured using a Likert scale. Likert scale is a scale used to measure attitudes, opinions, and perceptions of a person or a group of social phenomenon (Nike Rimawati, 2011). The interval assessment of Likert Scale consists of 4 points: 1) Strongly disagree, 2) Disagree, 3) Agree, 4) Strongly agree; and another 4 points: 1) Very dissatisfied, 2) Dissatisfied, 3) Satisfied, 4) Very satisfied. All questions / statements used to measure the variables in this study can be found in the annex to the questionnaire.

\section{Data Analysis Technique}

The data collected through questionnaires are then tabulated and obtained the average value of each of the respondents' answers. To facilitate the research, interval is created from the average values. In this study, the writers determine the number of class intervals, ie 4 (four). The formula used according to Zamruddin Hasid (2012: 3 ) is as follows:

$$
\mathrm{i}=\underline{\text { Distance }}
$$

C

Where,

i : class size (interval)

c : number of classes (in this study, the number of class $=4$ )

distance: the difference between the highest value and the lowest value in the data.

Based on the above formula, the length of the class interval is as follows:

$$
\begin{aligned}
\mathrm{i} & =\frac{4-1}{4} \\
& =0,75
\end{aligned}
$$

From the above calculation, it is obtained information as illustrated in the following table. 
Table of the Measurement of Respondent Opinion

Viewed from the Interval

\begin{tabular}{|l|l|l|}
\hline No. & Interval & Explanation \\
\hline 1. & $1.00-1.74$ & $\begin{array}{l}\text { Strongly disagree / Very } \\
\text { dissatisfied }\end{array}$ \\
\hline 2. & $1.75-2.49$ & Disagree / Dissatisfied \\
\hline 3. & $2.50-3.24$ & Agree / Satisfied \\
\hline 4. & $3.25-4.00$ & $\begin{array}{l}\text { Strongly Agree / Very } \\
\text { Dissatisfied }\end{array}$ \\
\hline
\end{tabular}

The data obtained from respondents, in which the average value has been sought, are analyzed using descriptive statistics to know the demographics of respondents, average respondents' answersand the standard deviation.

\section{Validity and Reliability Test}

Validity and reliability test of the data collection tool is conducted to determine the validity and reliability of the questionnaires beforetheyare sent to respondents. Reliability is tested by Cronbach Alpha statistics, provided that a construct or variable is said reliable, if the value of Cronbach Alpha> 0.60 (Ghozali, 2009 in Nike Rimawati, 2011). Validity is tested by bi-variety correlation between the respective indicator scores with a total score of the construct. If the result is significant (in other words, the correlation value $>0.30$ ), it means the questionnaire is said valid.

\section{Classical Assumption Test Autocorrelation Test}

Autocorrelation test aims to determine whether in the linear regression model used there is correlation among bully errors. Autocorrelation test in this study is conducted using Durbin-Watson test (DW-test). The symptom of non-existence of correlation among the bully errors in the regression model used is whenthe value of Durbin-Watson is greater than du, but smaller than 4 - du (Imam Ghozali 2005 in Kasidi, 2007). Decision making on the existence or non-existence of autocorrelation is presented in the following table:

Tabel Pengambilan Keputusan Ada Tidaknya Autokorelasi

\begin{tabular}{|c|c|c|}
\hline Zero Hypothesis & Decision & Criteria \\
\hline $\begin{array}{l}\text { No positive } \\
\text { autocorrelation }\end{array}$ & Rejected & $0<\mathrm{d}<\mathrm{dl}$ \\
\hline $\begin{array}{l}\text { No positive } \\
\text { autocorrelation }\end{array}$ & $\begin{array}{l}\text { No } \\
\text { decision }\end{array}$ & $\mathrm{dl} \leq \mathrm{d} \leq \mathrm{du}$ \\
\hline $\begin{array}{l}\text { No negative } \\
\text { autocorrelation }\end{array}$ & Rejected & $\begin{array}{l}4-\mathrm{dl}<\mathrm{d} \\
<4\end{array}$ \\
\hline $\begin{array}{l}\text { No negative } \\
\text { autocorrelation }\end{array}$ & $\begin{array}{l}\text { No } \\
\text { decision }\end{array}$ & $\begin{array}{l}4-\mathrm{du} \leq \mathrm{d} \leq \\
4-\mathrm{dl}\end{array}$ \\
\hline $\begin{array}{l}\text { No positive } \\
\text { or negative } \\
\text { autocorrelation }\end{array}$ & $\begin{array}{l}\text { Not } \\
\text { rejected }\end{array}$ & $\begin{array}{l}d u<d<4 \\
-d u\end{array}$ \\
\hline
\end{tabular}

Source: Imam Ghozali, 2005 in Kasidi, 2007

\section{Heteroscedasticity Test}

Heteroscedasticity test aims to test whether in the regression model there is inequality of variance from the residual of one observation to another observation. If the variance from the residual of one observation to another observation remains, it is called homoscedasticity. However, if it is different,it is called heteroscedasticity. A good regression model is homoscedasticity or there is no heteroscedasticity (Imam Ghozali, 2009 in Nike Rimawati, 2011). 
In this study, heteroscedasticity is done by looking at the graph of plots between the prediction of dependent variable value, ZPRED, andits residual, SRESID. The detection of the presence or absence of heteroscedasticity can be done by looking at the presence or absence of specific pattern on the graph of scatterplot between SRESID and ZPRED, where the Y axis is the $\mathrm{Y}$ that has been predicted, and the $\mathrm{X}$ axis is the residual (Y prediction - Y actual) that has beenstudentized (Ghozali, 2009 in Nike Rimawati, 2011).

\section{Hypothesis Test}

One of the objectives of this study is to test the hypothesis. Based on quantitative research paradigm, a hypothesis is an answer to the research problem which is rationally detected by theory. Therefore, to determine the theoretical answer contained in the statement of the hypothesis is supported by the facts gathered and analyzed in the data testing process (Nike Rimawati, 2011). The statistical tool used to test the hypothesis of this study is multiple regressions which include the coefficient of determination $\left(\mathrm{R}^{2}\right)$, model feasibility test $(\mathrm{F}$ statistical test), and individual significance test ( $t$ statistical test).

\section{Multiple Regressions Method}

Multiple regressions link one dependent variable to several independent variables in a single predictive model. Regression analysis aims to measure the strength of linear correlation between two variables or more that show the direction of the relationship between the dependent and independent variables
(Imam Ghozali, 2009 in Nike Rimawati, 2011). Multiple regression model used in this study is presented in the following equation:

$Y=a+6_{1} X_{1}+6_{2} X_{2}-6_{3} X_{3}+6_{4} X_{4}+e$

Where:

Y : The independence of government auditor

a : constant

b1-b4 : Regression Coefficient

$\mathrm{X} 1$ :Audit Experience

$\mathrm{X} 2$ : Knowledge

X3 : Level of Job stress

X4 : Reward

e : error

The effect of the independent variable on the dependent variable is tested using twosided t-test, with a confidence level of $90 \%$. The researchers take the confidence level of $90 \%$ because it is based on the belief of the researchers that this study has the confidence level of $90 \%$ (which is consistent with the slovin method used by establishingthe level of leniency by $10 \%$,in which according to Nike Rimawati(2011), generally the percentage of inaccuracy leniencydue to sampling errors that can be tolerated is $10 \%$. The criteria for making the decision to acceptance or rejection of any hypothesis is by lookingat the significance valueof $t$ count for each independent variable or by comparingbetween the value of $t$ count and the value of $t$ table.Ha is accepted, if the valueof $t$ count is significant or above the value of $t$ table. On the contrary,Ha is rejected, if the value of $t$ count is not significant or below the value of $t$ table. 


\section{Coefficient of Determination}

According to MudrajadKuncoro (2009: 240), coefficient of determination $\left(\mathrm{R}^{2}\right)$ essentially measures how far the ability of the model explainsthe variations of dependent variable. The value of coefficient of determination is between 0 (zero) and 1 (one). Small value of $\left(\mathrm{R}^{2}\right)$ indicates that the ability of independent variables to explain dependent variable is very limited. The value approaching to the independent variables provides almost all the information needed to predict the variation of the dependent variable (Imam Ghozali, 2009 in Nike Rimawati, 2011).

The fundamental weakness of the use of coefficient of determinationis biased against the number of independent variables included in the model. Each one additionto independent variable, then the value of $\mathrm{R}^{2}$ increases, no matter whether or not the variable significantly influences the dependent variable. Therefore, this study uses Adjusted $\mathrm{R}^{2}$, because its value can go up or down in accordance with the significance of independent variables added to the model.

The data in this study will be processed using Statistical Package for Social Sciences (SPSS) program. The hypothesis of this study is influenced by the significance of the variable coefficient concerned after testing. The hypothesis will be accepted if the significance value of the variable $<0.10$, or the hypothesis will be rejected if the significance value of the variable $>0.10$. The conclusion of the hypothesis is conducted based on t-test and F-test to test the significance of the independent variables on the dependent variable.

\section{Model Feasibility Test (F statistical test)}

F statistical test basically indicates whether all the independent variables in the model simultaneously havean effect on the dependent variable (MudrajadKuncoro, 2009: 239). The basis for decision making of $F$ test is done simply by looking at the significance value of F contained in the output of regression analysis using SPSS. If the significance value of $F$ is smaller than a (0.10), it can be said that the independent variables simultaneously have a strong relationship with the dependent variable.

\section{Partial Significance Test (t statistical test)}

Kuncoro (2009: 238), t statistical test basically shows how far the influence of an explanatory variable partially on the variation of the dependent variable. The t-test can also be done just by looking at the significance value of $t$ of each variablecontained in the output of regression analysis using SPSS. If the significance value of $t$ is smaller than a (assuming a real rate of 0.10 ), which is consistent with the level of leniency set by the researchers at the time of sampling determination using slovin method of $10 \%$ ), it can be said that there is a strong relationship between independent variables and dependent variable.

In summary, the conclusion of the hypothesis can be described as follows:

1. If Ha is accepted and Ho is rejected If the value of $t$ count is greater than the value of $t$ table ( $t$ count $>t$ table) and if the significance level is under a (assuming a rate of $10 \%$ or 0.10 ), it can be said that $\mathrm{Ha}$ is accepted and Ho is rejected 
2. If Ho is accepted and Ha is rejected If the value of $t$ count is smaller than $t$ table ( $\mathrm{t}$ count $<\mathrm{t}$ table) and if the significance level is above a (assuming a rate of $10 \%$ or $0.10)$, it can be said that Ho is accepted and Ha is rejected.

\section{DATA ANALYSIS AND DISCUSSION Profile of Respondents}

The respondents in this study are the government auditors working in BPKP Representative of East Kalimantan Province. The data collection is done by distributing questionnaires directly to government auditors of BPKP Representative of East Kalimantan Province. The questionnaires distributed are as many as 51 copies, on March 30, 2015.

Given the geographical condition, distance, location, and the busyness of each respondent, the deadline for the collection of the questionnaires is limited up to April 7, 2015.

Table of the Summary of Research Questionnaires Collection

\begin{tabular}{|l|r|}
\hline Explanation & $\begin{array}{l}\text { Number of } \\
\text { copies }\end{array}$ \\
\hline Questionnaires distributed & 51 \\
\hline Collected back: & \\
\hline $\begin{array}{l}\text { Total questionnaires } \\
\text { collected back \& responded }\end{array}$ & 34 \\
\hline $\begin{array}{l}\text { Total questionnaires } \\
\text { collected back \& not } \\
\text { responded }\end{array}$ & 3 \\
\hline $\begin{array}{l}\text { Total questionnaires } \\
\text { collected back }\end{array}$ & $\mathbf{3 7}$ \\
\hline $\begin{array}{l}\text { Questionnaires which are } \\
\text { not collected back }\end{array}$ & 14 \\
\hline
\end{tabular}

\begin{tabular}{|l|r|}
\hline $\begin{array}{l}\text { Questionnaires which cannot } \\
\text { be used }\end{array}$ & 4 \\
\hline $\begin{array}{l}\text { Questionnaires which can be } \\
\text { used }\end{array}$ & 33 \\
\hline Response rate:37/51 & $72.55 \%$ \\
\hline $\begin{array}{l}\text { Response rate which can be } \\
\text { used:33/51 }\end{array}$ & $64.71 \%$ \\
\hline
\end{tabular}

Source: Processed primary data, April 2015

Of the 51 questionnaires sent, total questionnaires collected back are 37 questionnaires, with the total questionnaires collected back and responded as many as 34 copies and the total questionnaires collected back and not responded as many as 3 copies. Total questionnaires that are not collected back are as many as 14 copies. Then, of the 37 questionnaires collected back, 4 questionnaires are unusable, 1 copy is not filled completely and 3 copies that are not completely filled (returned and not responded), so they cannot be included in the research data processing. Thus, the data from the questionnaires that can be processed are as many as 33 copies. Because the questionnaires which are collected back and get a complete response from the respondentsare only as many as 33 copies, only 33 government auditors, who collected back the questionnaires in full, which can be sampled in this study. This number has been adjusted to the sample criteria of correlated and causal research. Gay and Diehl in Kasidi (2007) say that for a correlated and causal study requires at least 30 samples to test the presence or the absence of relationship or influence. Results obtained from a sample of 33 respondents of this study are 27 male respondents and 6 female respondents, 
with the education level: Diploma Degree (D3) as many as 13 respondents, Bachelor Degree (S1) as many as 16 respondents, and Master Degree (S2) as many as 4 respondents. In which 12 respondents are from the field of Local Government Accountability (APD), 5 respondents are from the field of State Accountant (AN), 8 respondents are from the field of Central Government Agency (IPP), and 8 respondents are from the field of Investigation (INV) with 1Structural Rank, 8 Associate Auditors, 2 Young Auditors, 10 First Auditors and 12 Skilled Auditors, and14 respondents have working period of 0 to 4 years, 3 respondents have working period of
4 to 6 years, 1 respondent has working period of 6 to 10 years, 15 respondents have working period of more than 10 years.

\section{Description of Research Variables}

In order to give the description of the independent variables, consisting of audit experience, knowledge, job stress scale, and reward, and the dependent variable, consisting of the independence of government auditor, requires data processing using descriptive statistic with the aim to determine the values of variables in this study. Here is a summary of descriptive statistic of the research variables.

Table of the Summary of Descriptive Statistic of Research Variables

\begin{tabular}{|l|l|l|l|l|l|l|}
\hline No. & \multicolumn{1}{|c|}{ Variable } & $\mathrm{N}$ & Minimum & Maximum & $\begin{array}{l}\text { Mean } \\
\text { Value }\end{array}$ & $\begin{array}{c}\text { Standard } \\
\text { Deviation }\end{array}$ \\
\hline 1. & Audit experience & 33 & 1 & 4 & 2.76 & 0.993 \\
\hline 2. & Knowledge & 33 & 2.2 & 4 & 3.11 & 0.427 \\
\hline 3. & Job stress scale & 33 & 2 & 3.83 & 2.81 & 0.389 \\
\hline 4. & Reward & 33 & 2 & 4 & 2.74 & 0.502 \\
\hline & $\begin{array}{l}\text { Government Auditor } \\
\text { Independence }\end{array}$ & 33 & 2.6 & 4 & 3.21 & 0.346 \\
\hline
\end{tabular}

Source: Processed primary data, April 2015

The data obtained shows the number of respondents $(\mathrm{N})$ as many as 33. The first variable, audit experience, shows that the minimum responseof respondents is in the range of 1 and the maximum responseof respondents is in the range of 4 with the mean value of 2.76 and a standard deviation of 0.993 . The second variable, knowledge, shows that the minimum response of respondents is in the range of 2.2 and the maximum response of respondents is in the range of 4 with themean value of 3.11 and a standard deviation of 0,427 . The third variable, the level of job stress, shows that the minimum response of respondents is in the range of 2 and the maximum response of respondents is in the range of 3.83 with the mean value of 2.81 and a standard deviation of 0.389 . The fourth variable, reward, shows that the minimum response of respondents is in the range of 2 and the maximum response of respondents is 
in the range of 4 with the mean value of 2.74 and a standard deviation of 0.502. Meanwhile, the dependent variable, the independence of government auditor, shows that the minimum response of respondents is in the range of 2.6 and the maximum response of respondents is in the range of 4 with the mean value of 3.21 and a standard deviation of 0.346 .

\section{Validity and Reliability Test Research Instrument Validity Test}

Validity test is used to determine the validity and invalidity of questionnaires used in this study to the indicators that make up the construct of the study variables. The questionnaire is considered valid if the question / statement on the questionnaire is able to express something that is measured by the questionnaire. The validity test is performed using SPSS computer program by way of correlating the score of questions / statements with the total score of constructs.

The validity of the questionnaires of audit experience, knowledge, job stress scale, reward, and the independence of government auditor from SPSS display by checking the column corrected item-total correlation, then all the values of $r$ count obtained are bigger than $r$ table $(0.30)$, so the questionnaires that form the constructof variables of audit experience, knowledge, level of job stress, reward, and government auditor independence are valid. The summary of SPSS output display for testing the validity of the questionnaire of audit experience is as follows.

Table of the Summary of Data Validity Test

\begin{tabular}{|c|c|c|c|}
\hline Item & $\begin{array}{l}\text { r count (corrected item-total } \\
\text { correlation) }\end{array}$ & $r$ table & Explanation \\
\hline \multicolumn{4}{|c|}{ Audit Experience } \\
\hline q1 & 0.932 & 0.30 & Valid \\
\hline $\mathrm{q} 2$ & 0.778 & 0.30 & Valid \\
\hline \multicolumn{4}{|c|}{ Knowledge } \\
\hline $\mathrm{q} 1$ & 0.786 & 0.30 & Valid \\
\hline $\mathrm{q} 2$ & 0.676 & 0.30 & Valid \\
\hline $\mathrm{q} 3$ & 0.797 & 0.30 & Valid \\
\hline $\mathrm{q} 4$ & 0.777 & 0.30 & Valid \\
\hline q5 & 0.704 & 0.30 & Valid \\
\hline \multicolumn{4}{|c|}{ Job Stress Scale } \\
\hline $\mathrm{q} 1$ & 0.633 & 0.30 & Valid \\
\hline $\mathrm{q} 2$ & 0.767 & 0.30 & Valid \\
\hline $\mathrm{q} 3$ & 0.609 & 0.30 & Valid \\
\hline q4 & 0.684 & 0.30 & Valid \\
\hline q5 & 0.833 & 0.30 & Valid \\
\hline q6 & 0.357 & 0.30 & Valid \\
\hline
\end{tabular}




\begin{tabular}{|c|c|c|c|}
\hline \multicolumn{4}{|c|}{ Reward } \\
\hline $\mathrm{q} 1$ & \begin{tabular}{|l|l|}
0.825 \\
\end{tabular} & 0.30 & Valid \\
\hline $\mathrm{q} 2$ & \begin{tabular}{|l}
0.872 \\
\end{tabular} & 0.30 & Valid \\
\hline \multicolumn{4}{|c|}{ Government Auditor Independence } \\
\hline q1 & 0.618 & 0.30 & Valid \\
\hline $\mathrm{q} 2$ & 0.723 & 0.30 & Valid \\
\hline q3 & 0.802 & 0.30 & Valid \\
\hline q4 & 0.680 & 0.30 & Valid \\
\hline q5 & 0.673 & 0.30 & Valid \\
\hline
\end{tabular}

Source: Processed primary data, April 2015

\section{Reliability Test}

Reliability is used to measure a questionnaire as an indicator of variables. The questionnaire is considered valid, if someone's answers to the questionnaire are stable over time. Measurement of reliability in the study is conducted inone short using SPSS version 21. The decision taken is that a construct is said to be reliable if it produces a Cronbach alpha value greater than 0.60 (Imam Ghozali, 2009 in Nike Rimawati 2011). In this research, the test is conducted to measure the reliability ofaudit experience variable, knowledge variable, job stress scale variable, reward variable, and government auditor independence variable.

From the result of SPSS output is obtainedthe value of Cronbach alpha for the variables of audit experience, knowledge, level of job stress, reward and government auditor independence, in which all of them have a value above 0.60 . Thus, the questionnaires used to measure these variables are reliable. The results are specifically shown in the table below:

Table of the Summary of Data Reliability Test

\begin{tabular}{|l|l|l|l|}
\hline Variable & $\begin{array}{l}\text { Value of Cronbach's } \\
\text { Alpha }\end{array}$ & $\begin{array}{l}\text { Value of } \\
\text { Table }\end{array}$ & Explanation \\
\hline Audit Experience & 0.602 & 0.60 & Reliable \\
\hline Knowledge & 0.786 & 0.60 & Reliable \\
\hline Job Stress Scale & 0.736 & 0.60 & Reliable \\
\hline Reward & 0.608 & 0.60 & Reliable \\
\hline $\begin{array}{l}\text { Government Auditor } \\
\text { Independence }\end{array}$ & 0.726 & 0.60 & Reliable \\
\hline
\end{tabular}

Source: Processed primary data, April 2015 


\section{Classical Assumption Test Autocorrelation Test}

Autocorrelation test aims to determine whether in the linear regression model used in this study there is correlation between the bully error in period $t$ and the bully error in period $\mathrm{t}-1$. Autocorrelation often occurs in the time series data, but it is relatively seldom to occurin the cross-sectiondata. A good regression model is free of the occurrence of autocorrelation. Autocorrelation test in the study is conducted using Durbin-Watson test (DW-test).

Table of the Results of Autocorrelation Test

\begin{tabular}{|l|r|}
\hline Model & Durbin-Watson \\
\hline 1 & $1.799^{\mathrm{a}}$ \\
\hline
\end{tabular}

a. Predictors: (Constant), X4, X2, X1, X3

b. Dependent Variable: Y

Table 4.20 above showsthat the value of Durbin-Watson is 1.799. This value is compared with the value of Durbin-Watson on a table with a significance level of 0.10 , the number of samples (n) are 33, the number of independent variables are $4(\mathrm{k}=4)$, obtained the value of $\mathrm{du}$ $=1.73$ and the value $\mathrm{dl}=1.19$. Thus, the value $\mathrm{DW}=1.799$ greater than du but smaller than 4 - du $(1.73<1.799<2.27)$. The conclusion is that positive or negative autocorrelation does not occur in the regression model used in this study.

\section{Heteroscedasticity Test}

Testing the presence or absence of heteroscedasticity in the study is conducted by examining the graph plots between the value of the dependent variable, namely ZPRED, and the residual, namely SRESID. Meanwhile, determining the presence or absence of heteroscedasticity is done by looking at the existence or inexistence of specific pattern on the scatter-plot graph between SRESID and ZPRED with $\mathrm{Y}$ axis as the predicted $\mathrm{Y}$ and $\mathrm{X}$ axis as the residual (predicted $Y$ minus actual Y).

Basis of analysis: (1) if there is a particular pattern, for example,the existing dots form a regular particular pattern (wavy, widened and then narrowed), this indicates that there has been a heteroscedasticity, (2) if there isno a clear pattern, and the dots spread above and below number 0 (zero) on the $\mathrm{Y}$ axis, this indicatesthat there is no heteroscedasticity. Hereis the SPSS display to test the existence or inexistence ofheteroscedasticity.

\section{Graph of Heteroscedasticity Test}

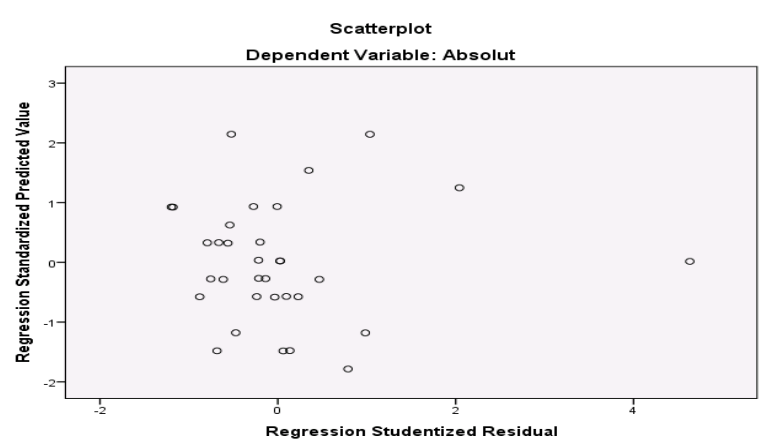

In the SPSS output display above, the scatter-plot graph shows that the dots randomly spread both above and below number 0 (zero) on the $\mathrm{Y}$ axis. It can be concluded that no heteroscedasticity occurs in the regression model used in this study, so this regression model is feasibleto predict the government auditor independence base on the input of the independent variables: audit experience, knowledge, level of job stress, and reward. 


\section{Hypothesis Test \\ Multiple Linear Regression Analysis}

Multiple linear regression formula is used to determine whether or not the independent variables (audit experience, knowledge, level of job stress, and reward) affect the dependent variable (government auditor independence). SPSS output display shows the following results:

$\mathrm{a}=1.047 ; \mathrm{b} 1=-0.063 ; \mathrm{b} 2=0.493 ; \mathrm{b} 3=0.090$;

$\mathrm{b} 4=0.202 ; \mathrm{R}$ square $=0.399 ;$ and adjusted $\mathrm{R}$ square $=0.313$.

From these results are obtained the regression equation as follows:

$\mathrm{Y}=1.047-0.063 \mathrm{X} 1+0.493 \mathrm{X} 2+0.090 \mathrm{X} 3+$ $0.202 \mathrm{X} 4$

\section{Coefficient of Determination}

Adjusted R square of 0.313 means that after the adjusted $\mathrm{R}$ square, $31.30 \%$ of the variation of the variable of government auditor independence is explained by the variablesof audit experience, knowledge, level of job stress, and reward owned or received by the government auditors and the remaining $68.70 \%$ is explained by variables outside the model.

\section{Model Feasibility Test (F Statistic Test)}

In this study, F statistic test is intended to determine whether the independent variables, consisting of audit experience, knowledge, level of job stress, and reward, simultaneously affect the independence of government auditors or not by looking at the significance level of the value of $F$ or comparingbetween the value of $F$ count and the value of $F$ table at the significance level of $10 \%$, with the dfnumerator is 4 (for $\mathrm{k}=4$ ), and df denominator is 29 (wheredf denominator $=\mathrm{n}-\mathrm{k}=33-4=$ 29). If the value of $F$ count is significant or greater than $\mathrm{F}$ table, the independent variables simultaneously have an effect on the dependent variable, and vice versa if the value of the $F$ count is insignificant or smaller than $\mathrm{F}$ table, the independent variables simultaneously do not have effect on the dependent variable. The SPSS output display indicates that the value of $F$ count is 4.653 , with a significance level of 0.05 , this means significant (because 0.05 $<0.10$, where, $\mathrm{a}=0.10$ or $10 \%$ ), while $\mathrm{F}$ table is 2.15 . The value of $F$ count is above 4.653, or above $\mathrm{F}$ table, then the conclusion is that the regression model used in this study can be used to predict the independence of government auditor, or it can be said that the independent variables (audit experience, knowledge, level of job stress, and reward) simultaneously have an effect on the dependent variable (the independence of government auditor).

\section{Partial Significance Test (t statistic test)}

From the SPSS output display is obtained explanation as. 
Table of the Summary of Accepted / Rejected Hypothesis

\begin{tabular}{|l|l|l|l|l|}
\hline Hypothesis & Value of t count & $\begin{array}{l}\text { Significance } \\
\text { level }\end{array}$ & $\begin{array}{l}\text { Value of one-sided } \\
\text { t table }\end{array}$ & Decision \\
\hline H1 & -0.973 & 0.339 & -1.699 & Rejected \\
\hline H2 & 3.028 & 0.005 & 1.699 & Accepted \\
\hline H3 & 0.529 & 0.601 & 1.699 & Rejected \\
\hline H4 & 1.695 & 0.101 & 1.699 & Rejected \\
\hline
\end{tabular}

Source: Processed primary data, April 2015

\section{DISCUSSION}

\section{Discussion Based on Simultaneous Significance Test}

From the data processing is obtained regression equation as follows:

$\mathrm{Y}=1,047-0,063 \mathrm{X} 1+0,493 \mathrm{X} 2+0,090 \mathrm{X} 3+$ $0,202 X 4$

From the regression equation above can be seen that the independent variable is constant, if it is on the position of zero, then the independence of government auditor is onthe position of 1.047 . If the factors that influence the government auditor independence increased by one point, the independence of auditor will increase by 0.722 points $(0.722=-0.063+0.493$ $+0.090+0.202)$ from the position of 1.047 to position of $1.769(1.047+1.769=0.722)$. This shows that the variables of audit experience, knowledge, level of job stress, and reward owned or acquired by the government auditors of BPKP Representative of East Kalimantan Province as the independent variables have a positive effect on the independence of the government auditor of BPKP Representative of East Kalimantan Province.

\section{Discussion Based on Partial Significance Test Hypothesis 1 (H1)}

Hypothesis 1 in this study formulates that audit experience has positive effect on the independence of government auditors of BPKP Representative of East Kalimantan Province. According to the evidence obtained from the response of the government auditors of BPKP Representative of East Kalimantan Province and after the data is processed, the result of data processing shows that the hypothesis cannot be accepted.

Based on the evidence, the value of $t$ count is insignificant or with a two-sided test is smaller than $t$ table. In variable of audit experience, Ho is accepted, which means that audit experience has no effect on the independence ofgovernment auditor. This is not in line with the research conducted by Kusharyanti (2003) and Gabriel Henry Willy Choandy (2012) that more experienced auditors have a better understanding of the financial statements so that the decisions taken could be better. Gabriel Henry Willy Choandy (2012) stated that an experienced auditor has advantages in terms of detecting errors, understanding errors accuratelyand finding the causes of the errors. The more experienced an auditor, the more 
sensitive the auditors to the errors found in the audit process. If an auditor is sensitive to unusual error that he found in the audit process, the auditor increasingly understands other matters related to the errors found. The more an auditor understands other matters related to errors that he found, the higher the degree of his independence as an auditor.

Rejection of this hypothesis indicates that the audit experience owned by a government auditor cannot affect the independence of a government auditor. This is because, when an auditor is in the field, he must maintainhis independence although he only has relatively short audit experience. Thus, it can be concluded that the audit experience owned by a government auditor cannot be a yardstick to determine whether a government auditor can be independent or not in every assignment.

\section{Hypothesis 2 (H2)}

Hypothesis 2 in this study formulates that knowledge has a positive effect on the independence of government auditorsof BPKP Representative of East Kalimantan Province. The construct of knowledge variable is formed through 5 questions / statements measured using 4-point Likert scale, starting from scale 1 , withthe category of strongly disagree, to scale 4 , with the category of strongly agree. The higher the scale, the higher the level of independence of a government auditor. The theoretical range of knowledge variable isfrom 2.20 to 4 for each respondent.

From the result of the responses of respondents is obtained an average rate of 3.11.
The average rate of 3.11 indicates the position of strongly agree. From partial hypothesis test is obtained a significant value of $t$ count and greater than the value of $t$ table. Based on these results, it can be concluded that $\mathrm{H} 2$ is accepted. It has a meaning that there is a positive influence between the knowledge of the government auditor and the independence of government auditor. This is in line with the research conducted by Gabriel Henry Willy Choandy (2012) that the knowledge possessed by the auditor has a significant effect onthe independence of an auditor. Gabriel Henry Willy Choandy (2012) stated that a highly educated auditor would have a broader view on various things. The auditor will increasingly have a lot of knowledge about the field that he does, so that he can find a variety of issues in depth. In addition, with enough knowledge, the auditor will be easier to follow the developments of the increasingly complex audit.

The acceptance of this hypothesis indicates that the knowledge possessed by the government auditor has positive effect on the independence of the government auditors of BPKP Representative of East Kalimantan Province. This indicates that the ability to analyze any information obtained related to auditing, careful attitudes in dealing with any issues that arise related to the examination, understanding of Accounting Standards (SAK), APIP Professional Standardsand Government Accounting Standards (SAP), formal education, training, courses, as well as special skills are very important for a government auditor to maintain his independence. 
Without having ability to analyze the information obtained related to auditing, careful attitudes in dealing with any issues that arise related to the examination, understanding of Accounting Standards (SAK), APIP Professional Standards and Government Accounting Standards (SAP), formal education, training, courses, as well as special skills, there is a possibility that a government auditor may produce false results of the examination report. Indirectly, it can affect the users of the examination results in terms of decision making. Thus, it can be concluded that it can reduce the independence level of a government auditor.

\section{Hypothesis 3 (H3)}

Hypothesis 3 in this study formulates that job stress scale has negative effect on the independence of the government auditor. The questionnaire for this variable consists of six questions / statements measured using 4-point Likert scale, starting from scale 1, which shows the category of strongly disagree, to scale 4 , which shows the category of strongly agree. The higher the scale, the higher the level of independence of a government auditor.

From this variable of job stress scale, the theoretical range to each respondent's answer is 2 to 3.83 . From the results of respondents' answers obtained and which can be processed, are gained an average of 2.81 . When compared to its theoretical range, an average of 2.81 is in a position ofweak "agree". From the results of partial hypothesis testing are found no strong evidence to accept the hypothesis 3. This implies that the job stress scale experienced by the government auditor does not affect his independence as a government auditor. This is not in line with the research conducted by Gabriel Henry Willy Choandy (2012) that there is significant effect between the level of job stress experienced by an auditor andhis independence as an auditor. Gabriel Henry Willy Choandy (2012) states that the workload or the job stress, either personal or emotional stress, can lead to reduced auditor independence and can affect the quality of the audit.

The rejection of this hypothesis indicates that the job stress scale experienced by a government auditor, both personally and interpersonally, has no influence on the independence of a government auditor. This is because, when a government auditor is in the field, the auditor should maintain his professionalism and should remain independent even when he is having problems on the job (in other words, he is experiencing stress to the job that he does). Thus, it can be concluded that the level of job stress experienced by a government auditor cannot be used as a yardstick to determine whether a government auditor may be independent or not in any execution of his duties.

\section{Hypothesis 4 (H4)}

Hypothesis 4 in this study formulates that reward has positive effect on the independence of government auditors of BPKP Representative of East Kalimantan Province. The construct ofthe variable of reward is formed through two questions / statements measured using 4-point 
Likert scale, starting from scale 1, indicating the category of very dissatisfied, to scale 4 , indicating the category of very satisfied. The higher the scale, the higher the level of independence of a government auditor.

From the variable of reward, the theoretical range to each respondent's answer is for each respondent's answer is from 2 to 4 . From the results of respondents' answers obtained are gained an average of 2.74. The average value of 2.74 indicates the position of a weak "agree". From the result of partial hypothesis test is obtained that the value of $t$ count is insignificant and smaller than the value of $t$ table. Therefore, it can be concluded that there is no influence between the reward received by the government auditor andthe independence of the government auditorsof BPKP Representative of East Kalimantan Province. This is not in line with the research conducted by Gabriel Henry Willy Choandy (2012) that there is a significant influence between reward and punishment received by an auditor and his independence as an auditor. Gabriel Henry Willy Choandy (2012) states that the factor of reward or compensation in the form of present or punishment or sanctions received by an auditor in performing the examination may affect the independence of the auditor in giving an opinion on the audit results.

The rejection of this hypothesis indicates that the reward received by a government auditor, both material and non material cannot affect his independence as a government auditor. This is because, when a government auditor is in the field, he still has tomaintain his independence as an auditor and he has to maintain his professionalism not to receive compensation of any kind from the auditee. Thus, it can be concluded that the reward received by a government auditor cannot be used as yardstickto ascertain a government auditor may be independent or not in every assignment.

\section{CONCLUSION AND SUGGESTIONS}

\section{Conclusion}

Based on the results of hypothesis verification of the data collected in this study can be summarized as follows:

1. Based on the results of simultaneous hypothesis testing, it can be concluded that audit experience, knowledge, job stress scale, and reward simultaneously havepositive effect on the independence of the government auditors of BPKP Representative of East Kalimantan Province.

2. Based on the results of partial hypothesis testing, it can be concluded as follows:

a) Audit experience has no effect on the independence of the government auditors of BPKP Representative of East Kalimantan Province.

b) Knowledge has positive effect on the independence of the government auditors of BPKP Representative of East Kalimantan Province.

c) The job stress scale has no effect on the independence of the government auditors of BPKP Representative of East Kalimantan Province. 
d) Reward has no effect on the independence of the government auditors of BPKP Representative of East Kalimantan Province.

\section{Suggestion}

The suggestions that can be put forward are as follows:

1. This research is expected to be a factor ofconsideration for policy makers, academics, researchers, and practitioners as a measuring tool for the implementation of the prevention of corruption in Indonesiaini.

2. This study is expected to provide an additional contribution to the development of a theory of behavior in the accounting literature concerning the factors that affect the independence of auditors, particularly government auditors in auditing environment.

3. This study is expected to increase insight, knowledge, understanding, and comprehensionfor the government auditors, governments, and the public about the factors that may affect the independence of government auditors that ultimately may indirectly reduce the quality of the audit.

4. This study is expected to increase knowledge for the writersabout the factors that mayaffect the independence of government auditors.

5. For future similar studies, it is expected to expand the study sample so that the object of the study is not confined to government auditors who work at BPKP Representative of East Kalimantan Province only. Thus, the generalizations can be compared between one group and another group so as to strengthen the research conclusions.

\section{REFERENCES}

Achmad Badjuri, 2012, Analysis Faktorfaktor yang Mempengaruhi Kualitas Hasil Pemeriksaan Audit Sektor Publik: Studi Empiris pada BPKP Perwakilan Jawa Tengah,

Vol. 1, No. 2, November, 120-135.

Arfan Ikhsan Lubis, 2010, Akuntansi Keperilakuan, Edisi 2, Salemba Empat, Jakarta.

Ec. Hanny Wurangian dan Muslich Anshori, 2006,Pengaruh Faktor Internal dan

Faktor Eksternal terhadap Independensi Auditor: Studi pada Kantor Akuntan Publik di Surabaya, Ekuitas, Vol. 10, No. 1, Maret, 1-20.

Friska Novitasari, 2004, Analisis Faktor-faktor yang Mempengaruhi Independensi Auditor, Skripsi Fakultas Ekonomi Jurusan Akuntansi,Universitas Katolik Soegijapranata, Semarang.

Gabriel Henry Willy Choandy, 2012,Faktor-faktor yang Mempengaruhi Independensi Auditor dalam Pemeriksaan Laporan Keuangan Pemerintah Daerah di Lingkungan Provinsi Sumatera Utara, Skripsi Program Studi A k u n t a n s i Fakultas Ekonomi, Universitas Sumatera Utara, Medan 
Ika Permata Indah, 2011, Analisis Independensi dan Pengalaman Eksternal yang Berpengaruh terhadap Kualitas Audit: Studi Kasus pada Kantor Akuntan Publik Komisariat Wilayah Bandung, Skripsi Program Fakultas Ekonomi, UNIKOM, Bandung.

Kasidi,2007,Faktor-faktoryangMempengaruhi Independensi Auditor: Persepsi Manajer Keuangan Perusahaan Manufaktur di Jawa Tengah, Tesis Program Pasca Sarjana Magister Sains Akuntansi, UNDIP. Semarang.

Messier, William F., et el, 2009, Auditing \& Assurance Services: A Systematic Approach, 4nd Edition, Hinduan, Nuri, dkk (terjemahan), Jasa Audit \&

Assurance: Pendekatan Sistematis, Edisi 4, Salemba Empat, Jakarta.

Mudrajad Kuncoro, 2009,Metode Riset untuk Bisnis dan Ekonomi: Bagaimana Meneliti dan Menulis Tesis, Edisi 3, Erlangga, Jakarta.

Nike Rimawati, 2011,Faktor-faktor yang Mempengaruhi Independensi Auditor, Skripsi Fakultas Ekonomi Jurusan Akuntansi, UNDIP, Semarang.

Peraturan Kepala BPKP Nomor 11 Tahun 2013 tentang Perubahan Ketujuh atas Keputusan Kepala BPKP Nomor: $\quad$ KEP-06.00.00-286/K/2001 tentang Organisasi dan Tata Kerja Perwakilan BPKP.
Pusdiklatwas BPKP, 2008,Modul Diklat pembentukan Auditor Ahli: Kode Etik dan Standar Audit, Bogor.

Sukrisno Agoes, 2012,Auditing: Petunjuk Praktis Pemeriksaan Akuntan oleh Akuntan Publik, Edisi 4 Buku 1, Salemba Empat, Jakarta.

Zamruddin Hasid, 2012,Pengantar Statistik Ekonomi, Mulawarman University Press, Samarinda. 


\section{APPENDIX 1 \\ RESEARCH QUESTIONNAIRE}

A. Closed Research Instruments - List of Frequently Asked Questions

Name of Respondent (may be filled / not)

Name of Work-field
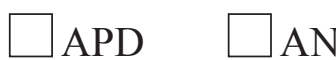

$\square$ IPP

Position

$\square$ Structural

Associate Auditor

$\square$ Young Auditor

First Auditor

$\square$ Skilled Auditor

Candidate of Functional Auditor

Education

$$
\begin{aligned}
& : \quad \square \text { D3 } \square \text { S1 } \square \text { S2 } \square \text { S3 } \\
& : \quad \square \text { Male } \square \text { Female } \\
& : \quad \square \text { to 4 years } \\
& \square \text { 4 to 6 years } \\
& \square \text { 6 toyears } \\
& \square \text { More than } 10 \text { years }
\end{aligned}
$$

Gender

Years of Service

\section{B. Closed Research Instruments}

\section{Audit Experience (X1)}

Explanation:

\begin{tabular}{|l|l|l|l|}
\hline Strongly disagree (1) & Disagree (2) & Agree (3) & Strongly agree (4) \\
\hline
\end{tabular}

\begin{tabular}{|l|l|l|l|l|l|}
\hline No. & Questions / Statements & \multicolumn{3}{|c|}{ Response } \\
\cline { 4 - 6 } & & $\mathbf{1}$ & $\mathbf{2}$ & $\mathbf{3}$ & $\mathbf{4}$ \\
\hline 1. & $\begin{array}{l}\text { I feel that my yearly service can support me in implementing } \\
\text { audit. }\end{array}$ & & & & \\
\hline 2. & I have audited many agencies, so my ability to audit is better. & & & & \\
\hline
\end{tabular}

2. Knowledge (X2)

Explanation:

\begin{tabular}{|l|l|l|l|}
\hline $\begin{array}{l}\text { Strongly disagree } \\
(1)\end{array}$ & Disagree (2) & Agree (3) & Strongly agree (4) \\
\hline
\end{tabular}




\begin{tabular}{|c|c|c|c|c|c|}
\hline \multirow[t]{2}{*}{ No. } & \multirow[t]{2}{*}{ Questions / Statements } & \multicolumn{4}{|c|}{ Response } \\
\hline & & 1 & 2 & 3 & 4 \\
\hline 1. & $\begin{array}{l}\text { I am able to analyze any information received related } \\
\text { to critical auditing. }\end{array}$ & & & & \\
\hline 2. & $\begin{array}{l}\text { I try to examine each of the issues arising in connection } \\
\text { with the examination. }\end{array}$ & & & & \\
\hline 3. & $\begin{array}{l}\text { I understand the Financial accounting Standards } \\
\text { (SAK), APIP Professional Standardsand Government } \\
\text { Accounting Standards (SAP) }\end{array}$ & & & & \\
\hline 4. & $\begin{array}{l}\text { In order to do audit well, I need knowledge from formal } \\
\text { education (Diploma 3, Bachelor S1, Professional } \\
\text { Education, Master Program S2, andDoctoral Program } \\
\text { S3) and from courses as well as training. }\end{array}$ & & & & \\
\hline 5. & $\begin{array}{l}\text { My specialty in knowledge of principles, practices, } \\
\text { and audit techniques support the audit assignment } \\
\text { that I do. }\end{array}$ & & & & \\
\hline
\end{tabular}

\section{Job Stress Scale (X3)}

\section{Explanation:}

\begin{tabular}{|l|l|l|l|}
\hline $\begin{array}{l}\text { Strongly disagree } \\
(1)\end{array}$ & Disagree (2) & Agree (3) & Strongly agree (4) \\
\hline
\end{tabular}

\begin{tabular}{|l|l|l|l|l|l|}
\hline No. & Questions / Statements & \multicolumn{3}{l|}{ Response } & \multicolumn{1}{l|}{} \\
\cline { 3 - 6 } & & $\mathbf{1}$ & $\mathbf{2}$ & $\mathbf{3}$ & $\mathbf{4}$ \\
\hline 1. & I am not depressed by the job I handle. & & & & \\
\hline 2. & Basically, I like my job. & & & \\
\hline 3. & Almost every day, I am enthusiastic about my job. & & & & \\
\hline 4. & $\begin{array}{l}\text { I often spend a long time until late at night to complete } \\
\text { my job. }\end{array}$ & & & \\
\hline 5. & $\begin{array}{l}\text { I would be very happy to spend the rest of my career } \\
\text { in this institution. }\end{array}$ & & & \\
\hline 6. & $\begin{array}{l}\text { I must obey the rules and policies applied to every } \\
\text { assignment. }\end{array}$ & & & & \\
\hline
\end{tabular}

\section{Reward(X4)}

\section{Explanation:}

\begin{tabular}{|l|l|l|l|}
\hline $\begin{array}{l}\text { Strongly disagree } \\
(1)\end{array}$ & Disagree (2) & Agree (3) & Strongly agree (4) \\
\hline
\end{tabular}

\begin{tabular}{|l|l|l|l|l|l|}
\hline No. & Questions / Statements & \multicolumn{4}{|l|}{ Response } \\
\cline { 3 - 7 } & & 1 & 2 & 3 & 4 \\
\hline
\end{tabular}




\begin{tabular}{|l|l|l|l|l|l|}
\hline 1. & $\begin{array}{l}\text { Government invests in employee compensation in } \\
\text { total (including welfare and pension funds). }\end{array}$ & & & \\
\hline 2. & $\begin{array}{l}\text { In your opinion, the career you choose gives more } \\
\text { opportunities to grow. }\end{array}$ & & & \\
\hline
\end{tabular}

\section{Independence (Y)}

\section{Explanation:}

\begin{tabular}{|l|l|l|l|}
\hline $\begin{array}{l}\text { Strongly disagree } \\
(1)\end{array}$ & Disagree (2) & Agree (3) & Strongly agree (4) \\
\hline
\end{tabular}

\begin{tabular}{|l|l|l|l|l|l|}
\hline No. & Questions / Statements & \multicolumn{3}{|l|}{ Response } & \\
\cline { 2 - 5 } & & $\mathbf{1}$ & $\mathbf{2}$ & $\mathbf{3}$ & $\mathbf{4}$ \\
\hline 1. & $\begin{array}{l}\text { The amount of my income will not affect me in } \\
\text { reporting the errors made by the clients/agencies that } \\
\text { I audit. }\end{array}$ & & & \\
\hline 2. & $\begin{array}{l}\text { I have a strong commitment to complete the audit } \\
\text { timely. }\end{array}$ & $\begin{array}{l}\text { I make APIP Professional Standardand Government } \\
\text { the field work. }\end{array}$ & & & \\
\hline 3. & $\begin{array}{l}\text { I do not easily believe the information provided by } \\
\text { the auditee during the auditing process without any } \\
\text { clear data. }\end{array}$ & $\begin{array}{l}\text { I always try to be careful in making decision during } \\
\text { the audit. }\end{array}$ & & & \\
\hline 5. & & & & \\
\hline
\end{tabular}

\section{APPENDIX 2}

\section{TEST OF DESCRIPTIVE STATISTICS, VALIDITY AND RELIABILITY}

\section{Descriptive Statistics}

\begin{tabular}{|l|r|l|l|l|l|l|l|}
\hline \multirow{2}{*}{} & N & Range & Minimum & Maximum & Mean & $\begin{array}{l}\text { Std. } \\
\text { Deviation }\end{array}$ \\
\cline { 2 - 7 } & Statistic & Statistic & Statistic & Statistic & Statistic & Std. Error & Statistic \\
\hline X1 & 33 & 3.000000 & 1.000000 & 4.000000 & 2.75757576 & .172878390 & .993110739 \\
X2 & 33 & 1.800000 & 2.200000 & 4.000000 & 3.10909091 & .074412298 & .427466107 \\
X3 & 33 & 1.833333 & 2.000000 & 3.833333 & 2.80808082 & .067700789 & .388911422 \\
X4 & 33 & 2.000000 & 2.000000 & 4.000000 & 2.74242424 & .087367898 & .501890366 \\
Y & 33 & 1.400000 & 2.600000 & 4.000000 & 3.21212121 & .060264187 & .346191399 \\
Valid N & 33 & & & & & & \\
(listwise) & & & & & & & \\
\hline
\end{tabular}


Test of Validity and Reliability

For Variable X1

Correlations

\begin{tabular}{|ll|r|r|r|}
\hline & $\begin{array}{l}\text { Audit } \\
\text { period }\end{array}$ & \multicolumn{1}{|c|}{$\begin{array}{l}\text { Number of } \\
\text { client }\end{array}$} & \multicolumn{1}{l|}{ Total } \\
\hline Audit period & Pearson & 1 & $.498^{* *}$ & $.932^{* *}$ \\
& Correlation & & .003 & .000 \\
& Sig. (2-tailed) & 33 & 33 & 33 \\
& N & Pearson & 1 & $.778^{* *}$ \\
Number of & Correlation \\
clients & Sig. (2-tailed) & .003 & & .000 \\
& N & 33 & 33 & 33 \\
& Pearson & $.932^{* *}$ & $.778^{* *}$ & 1 \\
Total & Correlation & .000 & .000 & \\
& Sig. (2-tailed) & 33 & 33 & 56 \\
\hline
\end{tabular}

**. Correlation is significant at the 0.01 level (2-tailed).

\section{Reliability}

\section{Scale: ALL VARIABLES}

Case Processing Summary

\begin{tabular}{|ll|r|r|}
\hline & \multicolumn{1}{|l|}{ N } & \multicolumn{1}{c|}{$\%$} \\
\hline \multirow{3}{*}{ Cases } & Valid & 33 & 57.9 \\
& Excluded $^{\mathrm{a}}$ & 24 & 42.1 \\
& Total & 57 & 100.0 \\
\hline
\end{tabular}

a. Listwise deletion based on all variables in the procedure.

Reliability Statistics

\begin{tabular}{|r|r|}
\hline $\begin{array}{l}\text { Cronbach's } \\
\text { Alpha }\end{array}$ & N of Items \\
\hline .602 & \\
& \\
\hline
\end{tabular}




\section{For Variable X2}

\section{Correlations}

\begin{tabular}{|c|c|c|c|c|c|c|c|c|c|}
\hline & & & \multicolumn{2}{|c|}{$\begin{array}{l}\text { Ability to } \\
\text { analyze }\end{array}$} & Accuracy & $\begin{array}{l}\text { Knowledge } \\
\text { of audit } \\
\text { principles }\end{array}$ & Education & Specialty & Total \\
\hline \multirow[t]{3}{*}{$\begin{array}{l}\text { Ability to } \\
\text { analyze }\end{array}$} & \multicolumn{2}{|c|}{ Pearson Correlation } & & 1 & $.433^{*}$ & $.678^{* *}$ & $.517^{* *}$ & $.379^{*}$ & $.786^{* *}$ \\
\hline & \multicolumn{2}{|l|}{ Sig. (2-tailed) } & .012 & .000 & .002 & .030 & .000 & & \\
\hline & $\mathrm{N}$ & 33 & 33 & 33 & 33 & 33 & 33 & & \\
\hline \multirow[t]{3}{*}{ Accuracy } & \multicolumn{2}{|c|}{ Pearson Correlation } & & $.433^{*}$ & 1 & $.521^{* *}$ & $.381^{*}$ & $.372^{*}$ & $.676^{* *}$ \\
\hline & Sig. (2-tailed) & .012 & & .002 & .029 & .033 & .000 & & \\
\hline & $\mathrm{N}$ & 33 & 33 & 33 & 33 & 33 & 33 & & \\
\hline \multirow[t]{3}{*}{$\begin{array}{l}\text { Knowledge } \\
\text { of audit } \\
\text { principles }\end{array}$} & \multicolumn{2}{|c|}{ Pearson Correlation } & & $.678^{* *}$ & $.521^{* *}$ & 1 & $.376^{*}$ & $.459^{* *}$ & $.797^{* *}$ \\
\hline & Sig. (2-tailed) & .000 & .002 & & .031 & .007 & .000 & & \\
\hline & $\mathrm{N}$ & 33 & 33 & 33 & 33 & 33 & 33 & & \\
\hline \multirow[t]{3}{*}{ Education } & \multicolumn{2}{|c|}{ Pearson Correlation } & & $.517^{* *}$ & $.381^{*}$ & $.376^{*}$ & 1 & $.439^{*}$ & $.777^{* *}$ \\
\hline & Sig. (2-tailed) & .002 & .029 & .031 & & .011 & .000 & & \\
\hline & $\mathrm{N}$ & 33 & 33 & 33 & 33 & 33 & 33 & & \\
\hline \multirow[t]{3}{*}{ Specialty } & \multicolumn{2}{|c|}{ Pearson Correlation } & & $.379^{*}$ & $.372^{*}$ & $.459^{* *}$ & $.439^{*}$ & 1 & $.704^{* *}$ \\
\hline & Sig. (2-tailed) & .030 & .033 & .007 & .011 & & .000 & & \\
\hline & $\mathrm{N}$ & 33 & 33 & 33 & 33 & 33 & 33 & & \\
\hline \multirow[t]{3}{*}{ Total } & \multicolumn{2}{|c|}{ Pearson Correlation } & & $.786^{* *}$ & $.676^{* *}$ & $.797^{* *}$ & $.777^{* *}$ & $.704^{* *}$ & 1 \\
\hline & Sig. (2-tailed) & .000 & .000 & .000 & .000 & .000 & & & \\
\hline & $\mathrm{N}$ & 33 & 33 & 33 & 33 & 33 & 33 & & \\
\hline
\end{tabular}

*. Correlation is significant at the 0.05 level (2-tailed).

**. Correlation is significant at the 0.01 level (2-tailed).

\section{Reliability}

Scale: ALL VARIABLES

Case Processing Summary

\begin{tabular}{|ll|r|r|}
\hline & \multicolumn{1}{l|}{ N } & \multicolumn{1}{l|}{$\%$} \\
\hline \multirow{3}{*}{ Cases } & Valid $^{*}$ & 33 & 100.0 \\
& Excluded $^{\mathrm{a}}$ & 0 & .0 \\
& Total & 33 & 100.0 \\
\hline
\end{tabular}

a. Listwise deletion based on all variables in the procedure.

\section{Reliability Statistics}




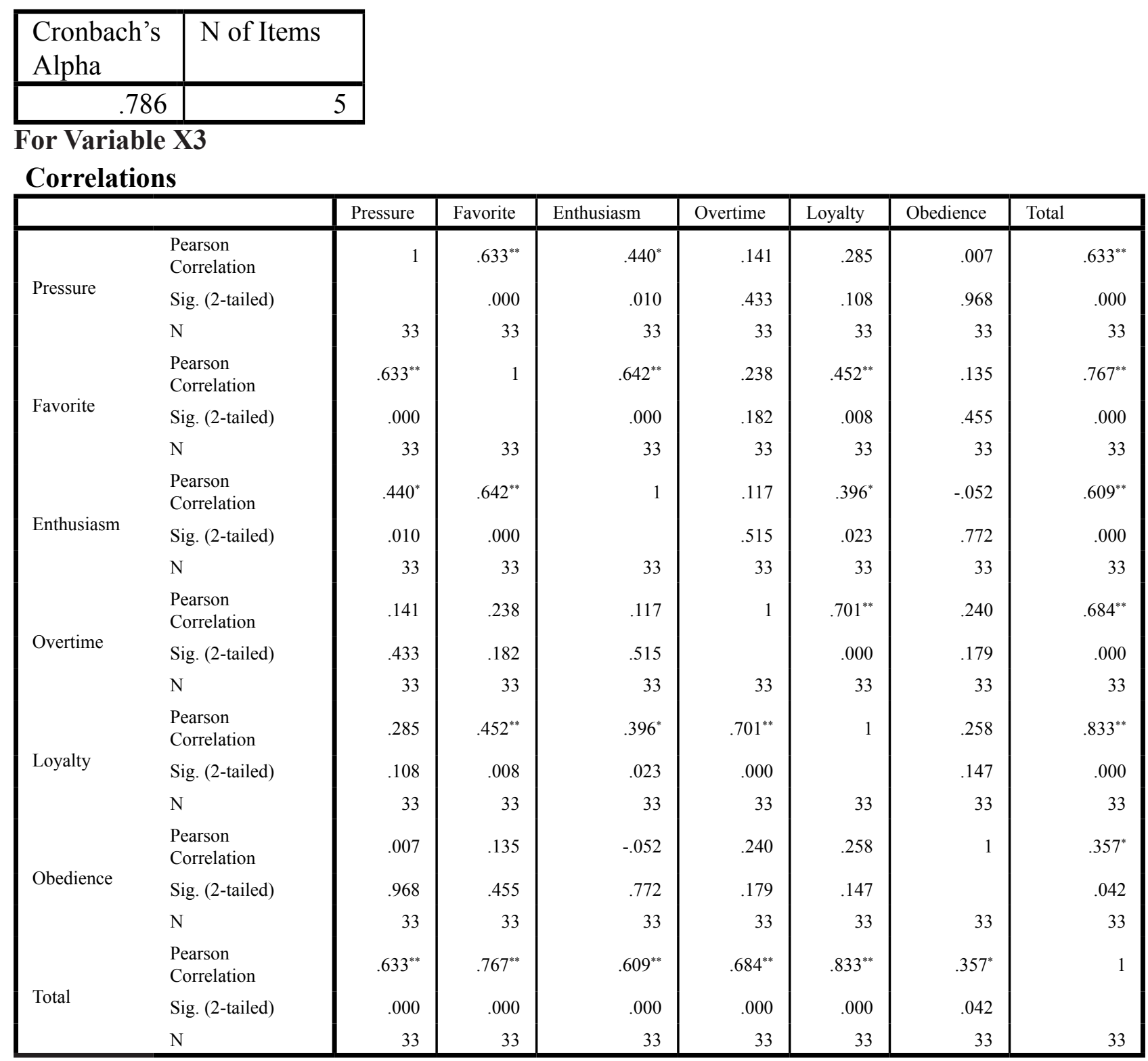

**. Correlation is significant at the 0.01 level (2-tailed).

*. Correlation is significant at the 0.05 level (2-tailed).

\section{Reliability}

Scale: ALL VARIABLES

Case Processing Summary

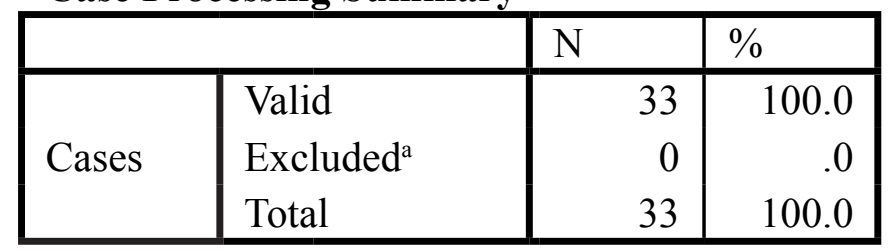


a. Listwise deletion based on all variables in the procedure.

Reliability Statistics

\begin{tabular}{|r|r|}
\hline $\begin{array}{l}\text { Cronbach's } \\
\text { Alpha }\end{array}$ & N of Items \\
\hline \multicolumn{2}{|r|}{.736 } \\
\hline
\end{tabular}

For Variable X4

\section{Correlations}

\begin{tabular}{|ll|r|r|r|}
\hline & & Compensation & Career & Total \\
\hline \multirow{5}{*}{ Compensation } & Pearson & 1 & $.442^{*}$ & $.825^{* *}$ \\
& Correlation & & .010 & .000 \\
& Sig. (2-tailed) & 33 & 33 & 33 \\
& $\mathrm{~N}$ & $.442^{*}$ & 1 & $.872^{* *}$ \\
& Pearson & .010 & & .000 \\
Career & Correlation & 33 & 33 & 33 \\
& Sig. (2-tailed) & $.825^{* *}$ & $.872^{* *}$ & 1 \\
& N & .000 & .000 & \\
& Pearson & 33 & 33 & 33 \\
\hline
\end{tabular}

*. Correlation is significant at the 0.05 level (2-tailed).

**. Correlation is significant at the 0.01 level (2-tailed).

\section{Reliability}

Scale: ALL VARIABLES

\begin{tabular}{|c|c|c|c|}
\hline & & $\mathrm{N}$ & $\%$ \\
\hline \multirow{3}{*}{ Cases } & Valid & 33 & 100.0 \\
\hline & Excluded $^{\mathrm{a}}$ & 0 & .0 \\
\hline & Total & 33 & 100.0 \\
\hline
\end{tabular}

a. Listwise deletion based on all variables in the procedure.

\section{Reliability Statistics}

\begin{tabular}{|r|r|}
\hline $\begin{array}{l}\text { Cronbach's } \\
\text { Alpha }\end{array}$ & N of Items \\
\hline .608 & 2 \\
\hline
\end{tabular}

For Variable Y

\section{Correlations}

\begin{tabular}{|l|l|l|l|l|l|l|}
\hline & $\begin{array}{l}\text { Free from } \\
\text { conflict of } \\
\text { financial } \\
\text { interests }\end{array}$ & Commitment & Guiding & Disbelieve & Cautious & Total \\
\hline
\end{tabular}




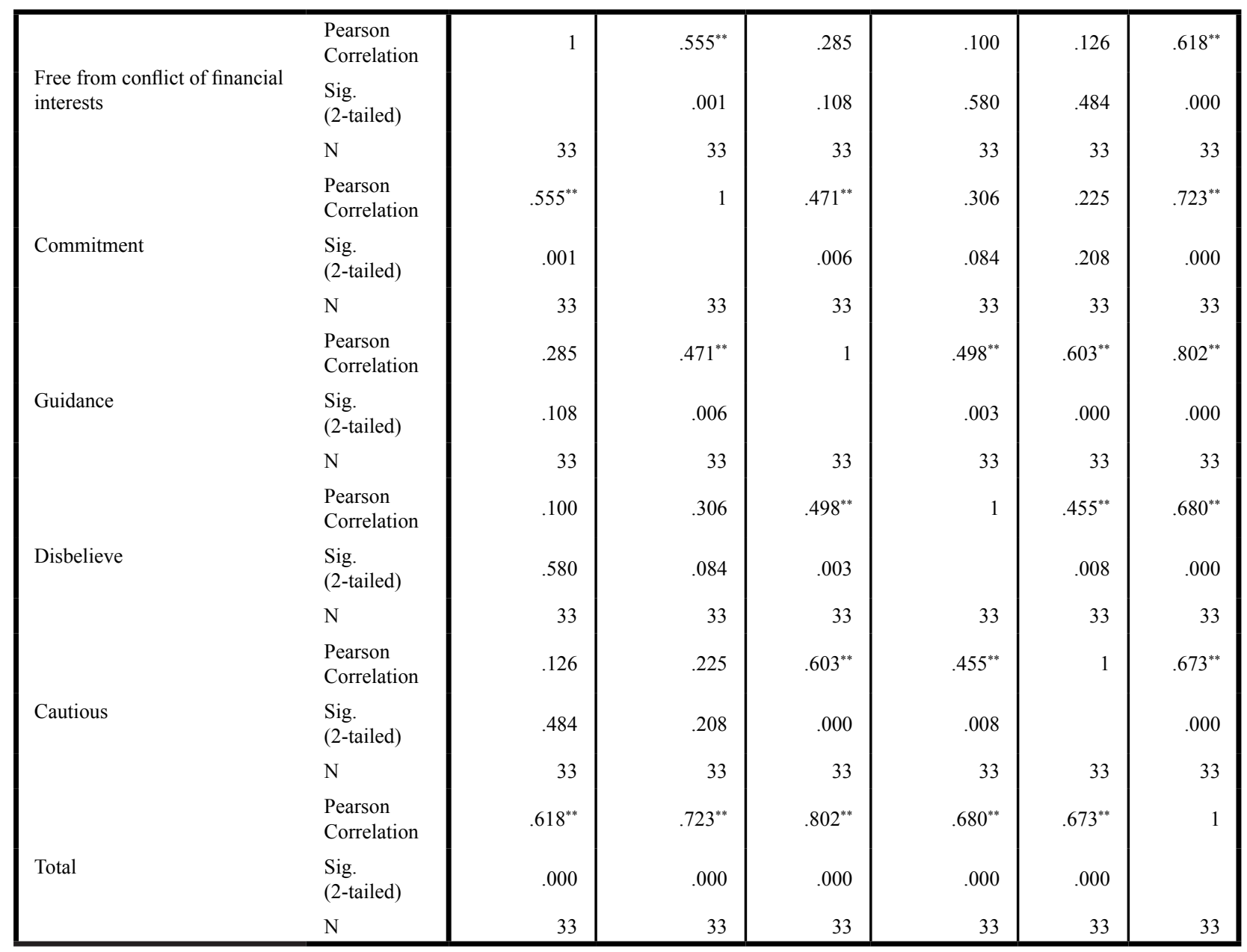

**. Correlation is significant at the 0.01 level (2-tailed).

\section{Reliability}

Case Processing Summary

\begin{tabular}{|ll|r|r|}
\hline & & $\mathrm{N}$ & \multicolumn{1}{l|}{$\%$} \\
\hline \multirow{3}{*}{ Cases } & Valid $^{2}$ & 33 & 100.0 \\
& Excluded $^{\mathrm{a}}$ & 0 & .0 \\
& Total & 33 & 100.0 \\
\hline
\end{tabular}

a. Listwise deletion based on all variables in the procedure.

Reliability Statistics

\begin{tabular}{|r|r|}
\hline $\begin{array}{l}\text { Cronbach's } \\
\text { Alpha }\end{array}$ & N of Items \\
\hline .726 & 5 \\
\hline
\end{tabular}

TEST OF CLASSICAL ASSUMPTION, COEFFICIENT OF DETERMINATION, AND MULTIPLE LINEAR REGRESSION

\section{Autocorrelation Test}


Variables Entered/Removed ${ }^{\text {a }}$

\begin{tabular}{|l|l|l|l|}
\hline Model & $\begin{array}{l}\text { Variables } \\
\text { Entered }\end{array}$ & $\begin{array}{l}\text { Variables } \\
\text { Removed }\end{array}$ & Method \\
\hline 1 & $\begin{array}{l}\text { X4, X2, } \\
\text { X1, X3 }\end{array}$ & & Enter \\
\hline
\end{tabular}

a. Dependent Variable: Y

b. All requested variables entered.

Model of Summary ${ }^{b}$

\begin{tabular}{|l|l|}
\hline Model & $\begin{array}{l}\text { Durbin- } \\
\text { Watson }\end{array}$ \\
\hline 1 & $1.799^{\mathrm{a}}$ \\
\hline
\end{tabular}

a. Predictors: (Constant),

$\mathrm{X} 4, \mathrm{X} 2, \mathrm{X} 1, \mathrm{X} 3$

b. Dependent Variable: $Y$

\section{Coefficient of Determination}

Variables Entered/Removed ${ }^{\mathrm{a}}$

\begin{tabular}{|l|l|l|l|}
\hline Model & $\begin{array}{l}\text { Variables } \\
\text { Entered }\end{array}$ & $\begin{array}{l}\text { Variables } \\
\text { Removed }\end{array}$ & Method \\
\hline 1 & $\begin{array}{l}\mathrm{X} 4, \mathrm{X} 2, \mathrm{X} 1, \\
\mathrm{X} 3^{\mathrm{b}}\end{array}$ & & Enter \\
\hline
\end{tabular}

a. Dependent Variable: $Y$

b. All requested variables entered.

Model Summary ${ }^{b}$

\begin{tabular}{|l|r|l|r|l|l|}
\hline Model & $\mathrm{R}$ & $\begin{array}{l}\mathrm{R} \\
\text { Square }\end{array}$ & $\begin{array}{l}\text { Adjusted R } \\
\text { Square }\end{array}$ & $\begin{array}{l}\text { Std. Error of the } \\
\text { Estimate }\end{array}$ & $\begin{array}{l}\text { Durbin- } \\
\text { Watson }\end{array}$ \\
\hline 1 & $.632^{\mathrm{a}}$ & .399 & .313 & .286842084 & 1.799 \\
\hline
\end{tabular}

a. Predictors: (Constant), X4, X2, X1, X3

b. Dependent Variable: Y

Multiple Linear Regression

Coefficients $^{\mathrm{a}}$

\begin{tabular}{|c|c|c|c|c|c|c|}
\hline \multirow{2}{*}{\multicolumn{2}{|c|}{ Model }} & \multicolumn{2}{|c|}{$\begin{array}{l}\text { Unstandardized } \\
\text { Coefficients }\end{array}$} & \multirow{2}{*}{$\begin{array}{l}\text { Standardized } \\
\text { Coefficients } \\
\text { Beta }\end{array}$} & \multirow[t]{2}{*}{$\mathrm{t}$} & \multirow[t]{2}{*}{$\overline{\text { Sig. }}$} \\
\hline & & $\mathrm{B}$ & Std. Error & & & \\
\hline \multirow{5}{*}{1} & (Constant) & 1.047 & .510 & & 2.051 & .050 \\
\hline & $\mathrm{X} 1$ & -.063 & .064 & -.179 & -.973 & .339 \\
\hline & $\mathrm{X} 2$ & .493 & .163 & .609 & 3.028 & .005 \\
\hline & $\mathrm{X} 3$ & .090 & .170 & .101 & .529 & .601 \\
\hline & $\mathrm{X} 4$ & .202 & .119 & .292 & 1.695 & .101 \\
\hline
\end{tabular}

a. Dependent Variable: $\mathrm{Y}$ 


\section{F statistic Test and t statistic Test}

ANOVA ${ }^{a}$

\begin{tabular}{|rl|r|r|r|r|r|}
\hline Model & \multicolumn{1}{l|l}{$\begin{array}{l}\text { Sum of } \\
\text { Squares }\end{array}$} & df & \multicolumn{1}{l|}{$\begin{array}{l}\text { Mean } \\
\text { Square }\end{array}$} & F & Sig. \\
\hline \multirow{3}{*}{1} & Regression & 1.531 & 4 & .383 & 4.653 & $.005^{\mathrm{b}}$ \\
& Residual & 2.304 & 28 & .082 & & \\
& Total & 3.835 & 32 & & & \\
\hline
\end{tabular}

a. Dependent Variable: Y

b. Predictors: (Constant), X4, X2, X1, X3

\section{Coefficients ${ }^{\mathrm{a}}$}

\begin{tabular}{|c|c|c|c|c|c|c|}
\hline \multicolumn{2}{|c|}{ Model } & \multicolumn{2}{|c|}{ Unstandardized Coefficients } & $\begin{array}{l}\text { Standardized } \\
\text { Coefficients } \\
\text { Beta }\end{array}$ & $\mathrm{T}$ & Sig. \\
\hline \multirow{5}{*}{1} & (Constant) & 1.047 & .510 & & 2.051 & .050 \\
\hline & X1 & -.063 & .064 & -.179 & -.973 & .339 \\
\hline & X2 & .493 & .163 & .609 & 3.028 & .005 \\
\hline & X3 & .090 & .170 & .101 & .529 & .601 \\
\hline & X4 & .202 & .119 & .292 & 1.695 & .101 \\
\hline
\end{tabular}

a. Dependent Variable: $Y$ 
Tomy Michael : Corruption and Niccolo Machiavelli.....

Page 263-274 